UDC 159.9.07

DOI https://doi.org/10.24919/2308-4863/35-5-34

Maryna RYZHENKO, orcid.org/0000-0002-0961-3351

Candidate of Pedagogical Sciences, Associate Professor at the Department of Foreign Languages O. M. Beketov National University of Urban Economy in Kharkiv (Kharkiv,Ukraine) marina.ryzhenko.89@ukr.net

Olena ANISENKO, orcid.org/0000-0003-3266-4584

Senior Teacher at the Department of Foreign Languages O. M. Beketov National University of Urban Economy in Kharkiv (Kharkiv,Ukraine) anisenko.e@gmail.com

Kostiantyn MISCHENKO, orcid.org /0000-0003-0872-9966

Senior Teacher at the Department of Foreign Languages O. M. Beketov National University of Urban Economy in Kharkiv (Kharkiv,Ukraine) kostyamischenko@yahoo.com

\title{
DEVELOPMENT OF LEADERSHIP POTENTIAL OF STUDENTS IN THE CONDITIONS OF DISTANCE LEARNING
}

\begin{abstract}
The article is devoted to the issues of formation and conditions of development leadership qualities of students in distance learning. In the context of recent educational reforms in Ukraine, which focus on increasing attention to education, the country needs not only highly qualified specialists, but also professionals with certain leadership qualities. The current state of Ukraine is characterized by its desire to integrate into the European Community in economic, political and educational aspects. In the conditions of quarantine caused by the COVID-19 epidemic, and as a consequence of distance learning, this process requires restructuring the higher education system as a priority area of forming a new society, modernizing its content and improving the learning process based on scientific approaches etc. Today, the development of technological means of telecommunications and communication, mass distribution and use of multimedia computer programs creates objective preconditions for the improvement of educational technologies, in particular, for the introduction of new forms of education for the general population, including distance learning. The article analyzes the definition the concept of "leader", leadership potential and ways of pedagogical support for the development of leadership potential in distance learning. The main attention is paid not only psychological assessment of the main approaches to understanding the nature of the phenomenon of the leader, but also the characteristics of the nodal points in the theoretical understanding of the essence formation of leadership qualities in students. Described teaching tools and methods that, in our opinion, are the most effective in process of formation of leadership qualities of students during distance education. The pedagogical conditions of educational process which will promote development of leadership qualities of students at the expense of interaction based on group forms of organization of the educational process, interactive and problem-based teaching methods, in particular the use of global networks and creative projects. Identified the main qualities needed by the leader student environment.
\end{abstract}

Key words: leader, leadership potential, student, teacher, distance education, distance learning.

Марина РИЖЕНКО, orcid.org/0000-0002-0961-3351 кандидат педагогічних наук, дочент кафедри іноземних мов Харківського національного університету міського господарства імені О. М. Бекетова (Харків, Україна) marina.ryzhenko.89@ukr.net

Олена АНІСЕНКО, orcid.org/0000-0003-3266-4584 стариий викладач кафедри іноземних мов Харківського націіонального університету міського господарства імені О. М. Бекетова (Харків, Україна) anisenko.e@gmail.com 


\title{
РОЗВИТОК ЛІДЕРСЬКОГО ПОТЕНЦАЛУ СТУДЕНТІВ В УМОВАХ ДИСТАНЦИЙНОГО НАВЧАННЯ
}

\begin{abstract}
Статтю присвячено питанням формування та умовам розвитку лідерських якостей студентів в умовах дистанційного навчання. У контексті освітніх реформ в Україні, шуо відбуваються впродовж останнього часу й зорієнтовують на підвищення уваги до освіти, країна потребує не тільки висококваліфікованих спеціалістів, але й професіоналів із певними лідерськими якостями. Сучасний стан Украӥни характеризується ї̈ прагненням до інтеграчї в Свропейське співтовариство як в економічному, політичному, так $і$ в освітньому аспектах. В умовах карантину, який виник через епідемію COVID-19 та, як наслідок, дистанційної форми навчання цей проиес потребує перебудови системи вищої освіти як пріоритетної сфери формування громадянина нового суспільства, модернізачії ї̈ змісту та вдосконалення прочесу навчання на основі використання наукових підходів, упровадження новітніх технологій тощзо. Нині розвиток технологічних засобів телекомунікачій $i$ зв 'язку, масове поширення та використання мультимедійних комп'ютерних програм створюють об'єктивні передумови для вдосконалення освітніх технологій, зокрема й для впровадження нових форм здобуття освіти, наприклад дистанційної, широкими верствами населення. Розвиток лідерського потенціалу молоді є актуальною проблемою для вищих навчальних закладів, оскільки саме у студентські роки відбувається активне формування ціннісних орієнтацій, громадянської позииії, визначення життєвих пріоритетів молодої людини. Невіддільним складником кожного університету є студентський актив, який має можливість самостійно ухвалювати рішення, нести за них відповідальність, висувати та реалізовувати сочіальні ініціативи, розвиваючи лідерський потенціал. Саме тому з метою створення лідерів нової генерації набуває актуальності проблема розвитку лідерського потенціалу студентського активу. У статті аналізується визначення поняття «лідер», лідерський потенціал і иляхи педагогічної підтримки розвитку лідерського потениіалу в умовах дистаниійного навчання. Водночас основну увагу приділено не тільки психологічній оцінці основних підходів до розуміння природи феномена лідера, а й характеристиці вузлових точок у теоретичному розумінні самої сутності формування лідерських якостей у студентів. Описано засоби йметоди навчання, які, на нашу думку, є найбільш ефективними у процесі формування лідерських якостей студентів під час дистанційної освіти. Проаналізовано педагогічні умови навчального процесу, які сприятимуть розвитку лідерських якостей студентів завдяки взаємодіі, основаній на групових формах організації навчального процесу, інтерактивних і проблемних методах навчання, зокрема застосуванні глобальних мереж і творчих проєктів. Визначено головні якості, потрібні лідеру в студентському середовищі.
\end{abstract}

Ключові слова: лідер, лідерський потенціал, студент, викладач, дистанційна освіта, дистанційне навчання.

Problem statement and its urgency. Due to the rapid spread of COVID-19, no one today has any doubts about the need to transform approaches to training, taking into account the consequences of the introduction of computer networks and technologies, new means of access, storage and exchange of information, including knowledge and educational information. One of the possible changes in the education system is the use of distance learning technologies, the main element of which is a distance course - a combination of special software and hardware two components: educational content and methods of student work with this content. On the basis of the distance course, distance learning is organized, which includes, in addition to the independent work of the student with the distance course and additional sources, communication of students with the teacher and with other students. With this approach, in addition to the undeniable advantages, there are problematic issues, one of which - ensuring the quality of such education, the second - the lack of normal interaction between participants. The means of communication in distance learning are insufficiently researched and there are almost no technologies for the formation of individual personal qualities. The issue of formation of not only professional, but also personal qualities, in particular leadership qualities, during the organization of distance learning acquires its urgency. In the article the problem of formation of leadership qualities is narrowed to the study of the process of creating a distance learning course on the basis of leadership by a group of teachers and narrow specialists. The problem of training future leaders is one of the important ones problems, and in modern conditions - one of the main problems in higher pedagogy education.

The purpose of this article is to determine the possibility of using a variety of approaches to the development of leadership potential in the organization of distance learning, namely, in the process of creating a distance course by a team of professionals. 
Research analysis Many domestic and foreign educators, psychologists, sociologists, political scientists pay serious attention to the problem of leadership and leadership qualities of the individual [Burns, 1978: 2]. They explore the most favorable conditions for the formation of confidence in the individual to choose leadership positions, create methods for the formation of leadership qualities and the development of leadership potential of students (Кращенко, 2009: 6) The vast majority of theoretical and methodological provisions and justifications for the content of pedagogical creativity and the technology of its formation can be generally used to solve the problem of training professional leaders. This is evidenced by the work of such scientists as Yu. Babansky, G. Ball, L. Vygotsky, S. Goncharenko, I. Zyazyun, V. Kremen, O. Leontiev, A. Ligotsky, V. Lugovy, V. Molyako, N. Nychkalo, P. Perepelytsia, Z. Reshetova, V. Rybalko, S. Sysoeva, B. Yudina and others. The results of these studies were theories of leadership, the most famous of which are the theory of traits of the leader E. Bogardus, K. Byrd, W. Binham, the theory of situational leadership G. Person, M. Belbin, P. Drucker, system leadership theory F. Fiedler and others.

The history of studying the concepts of "leader" and "leadership" actively begins in the middle of the last century. The term "leader" was borrowed from the ancient Greek language " $\gamma \gamma \varepsilon \dot{\varepsilon} \tau \eta \varsigma$ ", which means "one who leads", is the leader. The concept of "leadership" appeared later and expressed the already existing position of the leader in a particular team. Scientists such as J. Gerry, R. Tannenbaum, I. Wegner, and others have made a significant contribution to the development of these concepts. Modern psychological and pedagogical approaches show that the concept of "leadership" is multifaceted and is reflected in various sciences: psychology, pedagogy, sociology, political science. But their work, in our opinion, can not be considered separately, because each of the disciplines brings its own vision of the problem. For foreign scholars, in particular J. Maxwell, the idea of leadership is inseparable from the concept of influence.Domestic researchers of social psychology N. Kornev and A. Kovalenko understand leadership as one of the processes of organizing a small social group and managing it, which contributes to achieving the group goal in the optimal time and with the optimal effect.Accordingly, each leading school has tried and is trying to outline the basic qualities or traits of a person who is or can formally become a leader. Yu. Krashchenko notes that leadership in the student environment and self-government are two closely interrelated phenomena of the educational environment of higher education (Кращенко,
2009: 6). The following classifications of types of leaders are distinguished in the scientific literature according to leadership style: 1) authoritarian (rigid way of governing, prevention of initiative), democratic (assumes collegial decision-making, taking into account opinions and wishes of group members), liberal (indulgence style, group members make decisions almost independently, suitable for a team of like-minded people, each of whom is well aware of "their maneuver"), compromise (achieves its goal, giving way to people with different interests);2) business (involves work on calculated, orderly and optimal schemes) and emergency (manages on the principle of "do it quickly, let's understand later").

Almost all concepts of leadership emphasize the importance of effective cooperation of the leader with followers, which shows that leadership as a social phenomenon of organization of joint activities and management, social activity is a regulator in the system of interpersonal relations and can be manifested only in social groups. Teachers who are curators of student groups observe the spiritual, psychological, ideological state of students. Students, especially freshmen, try to be active and participate in various activities, which have a positive effect on their emotional state and in relationships with classmates and teachers. But to interest them, to reveal their abilities for leadership, it is necessary to have an experienced leader, i.e. a curator, and the appropriate level of student self-government. It should be borne in mind that the curator must realize that he has a responsibility not only as a teacher of a school, but also as a mentor who must unite the team, organize the work of the group, to reveal its atmosphere. In the process of learning it is necessary to take into account that the student age is characterized by the maximum in achieving positive results, mastering stereotypes of behavior and the formation of professional orientation. But in today's complex conditions of distance learning, this task is much more complicated due to the fact that the curator and teachers are much more difficult to establish contact with their students. The most important role in supporting the development of student leadership potential is played by various student associations, where students communicate with each other and together with teachers and administrators solve certain problems and achieve their goals. The issue of forming leadership qualities in distance learning is quite new, so there are not many publications on this topic. Thus, in particular, D. McFarlane considers the main leadership roles of curators and teachers of distance learning, which, in his opinion, performing managerial and monitoring functions, should motivate and encourage other participants in the process to use value and qual- 
ity teaching and learning methods. Distance learning professionals must also have the skills to collaborate, be focused and succeed. Thus, according to D. McFarlane, the administrator of distance learning must have leadership skills and be adapted to constant change. One of the ways to form these skills can be the process of developing a distance course, which chronologically precedes the organization of the learning process. Nowadays, the implementation of leadership ideas is a prerequisite for success. To implement leadership ideas in distance learning, you must first determine the list of required leadership qualities. This will clarify in further research what qualities should be formed in the participants in the process of organizing distance learning. D. Burns in his book "Leadership" defines leadership as leadership in which leaders focus on the relationship between leader and follower, as well as on the formation of beliefs in followers. Certain personal qualities of a leader (high intelligence, charisma, initiative, self-confidence, reliability, activity, responsibility, etc.) are necessary but not sufficient conditions for leadership. Leadership is a process that requires a person to be able to look at the future and on this basis to unite the team around him; it is a person who takes responsibility for other people. The leader must be open to change, risks. Continuous learning and self-improvement are important for this. Leadership qualities today are the ability to create in the team an identical vision of the current state and future, motivation, trust and mutual responsibility. Most modern researchers associate the ability to make changes, motivate others, and establish a team with emotional intelligence - the ability to manage emotions, both one's own and others'. The concept of emotional intelligence began to be used systematically with the research of D. Goleman (Goleman, 1998: 3). For distance learning, the issues of work organization and leadership formation in virtual teams are important.

Various scientists identify the following conditions for creating a successful team in distance learning: trust, understanding of goals and objectives, relationships between team members, communication, successful choice and use of technology, distribution of responsibilities and time, time control and performance correction (Bergiel, B. J., Bergiel, E. B., \& Balsmeier, P. W., 2008: 4). The technology of creating a distance course is considered in the works of S. Kalashnikova (Калашнікова, 2003: 5), V. Bykova, V. Kukharenko, N. Sirotenko, O. Rybalko.

T. Andersoni and D. Drone consider the following as the main models of distance learning:

- cognitive model, which is based on the theory of behaviorism and takes into account the limited technical resources at the beginning of the history of distance learning, focuses on the individualization of learning;

- social-constructivist model, which is focused on learning in groups, gaining knowledge both individually and in groups, i.e. as a result of teamwork (but it should be noted that the implementation of these models in real learning technologies is difficult);

- the constructivist model provides for the creation of opportunities for dialogue and cooperation in asynchronous contexts, based on technologies that support a significant number of opportunities for social presence and confidence building in group work;

- connectivist model involves the creation of networks of information, contacts and resources that are applied to real problems. As we can see, three of the four models of distance learning are related to groups, i.e. they involve working in teams in new conditions.

If the university is developing a distance course, then for its successful operation must be created prerequisites that include the following measures:

- determining the place of distance learning in the priorities of the university development strategy, compliance with the ideas of implementing distance learning mission of the university, awareness of the staff of the institution the need to use distance learning; - creation of technical conditions for the organization of distance learning courses: server equipment, appropriate software and distance learning platform, Internet access, service; - development of normative documents that regulate the process of organizing distance learning, in particular the requirements for the distance learning course, its content, use of elements and activities, quality assurance and its examination; - creation of departments for coordination of work on the organization of distance learning, its technical, methodical, service support and for adaptive assistance during training; - training of staff and teachers to use distance learning technologies.

In this way, groups are created, formal teams are formed, which can become real teams, united by separate goals and in which specialists with the qualities of a leader are formed. In addition, the development of distance learning courses establishes different relationships between the participants in the development of distance learning courses and the coordination and support departments. Situational informal teams are created to develop a distance course, for the effective operation of which the use of leadership is important. When developing a distance course, a separate question arises: "Do you need a team when developing a distance course, or is it better to develop it alone as a teacher, sometimes asking for help, but without teamwork?". The peculiarity of the team is that it unites, as a rule, people with different types of thinking, includ- 
ing students, specialists in computer and software technology and teachers, methodologists and other professionals.

The process of developing a distance course usually includes the following stages: - designing the main idea and strategy of the distance course; - recognition of the goals of the distance course, designing the expected learning outcomes in the form of competencies; - definition and design of the content of the distance course; - planning and design of the educational process (educational activities) in the distance course; - adaptation of the educational text to the requirements of the distance course;

- recording of educational videos; - development of practical tasks; - designing activities in the distance course; - planning of means of communication in a distance course; - organization of control and self-control in the course; - technical implementation; - development of graphic design; - development of methodical recommendations on work with a course; - development of standard recommendations for individualization of training; - examination of the distance course.

The process of developing a distance course is connected with the mechanisms of introducing the course into the educational process and feedback: feed-back of students and correction of the course content.

Such team should not be formed by administrative methods, but situationally. Management can create certain conditions, carry out appropriate communication activities that inspire employees to work in a team, cultivate the principles of democracy and leadership. Participants communicate with each other during discussions, round tables, workshops and meetings, brainstorming, feedback by various means not only in person, but also using technical means (video conferencing, online meetings, etc.). A commitment to openness, a shared vision of problem solving, achieving results and basic principles of team work during the development of a distance course allow the team to learn, develop collective thinking, form systematic and critical thinking in team members and develop leadership potential. Among the leadership qualities, competencies that need to be formed in the members of the team developing a distance course should be: the ability to see the future and strategic thinking, trust in people, openness to new ideas, desire for continuous learning and self-improvement, innovation, integrity, communication skills. From the point of view of emotional intelligence, in order to form an effective team and form these competencies, it is necessary to involve all its members in inspired conscious activities aimed at achieving a common goal. People in the team who can motivate and inspire, organize change, are already situational informal leaders in the development of a distance course. Joint activities and the process of involvement contribute to the creation of a special microclimate in the team, and participation in changes in new projects (development of a distance course is also a project) forms self-esteem, self-actualization and gives a feeling of good mood. The division of a group of people by function depending on the profession does not solve the question of the distribution of team roles in the process of creating a distance course, even if there is a person who is a formally appointed coordinator. For effective team work, it is advisable to determine the inclination of the participants and use their individual characteristics in effective teamwork.

Conclusions. Thus, based on the study of the possibilities of integrating leadership approaches in the process of organizing distance learning, in particular the development of distance learning, we can state the creation of new opportunities to ensure the quality of distance learning through the application of leadership approaches. Based on the analysis of the stages of creating a distance course, the composition of the team for the development of a distance course is proposed. It is established that the formation of leadership qualities in the team of distance course developers allows transforming of the approaches to assigning the responsibility of team members to perform professional tasks and to interact in a team.

\section{BIBLIOGRAPHY}

1. Burns, J. M. Leadership. New York : Harper \& Row, 1978. 355 p.

2. Goleman, D. Working with emotional intelligence. Bantam, 1998. 147 p.

3. Bergiel, B. J., Bergiel, E. B., Balsmeier, P. W. (2008). Nature of virtual teams: a summary of their advantages and disadvantages. Management Research News. 2008. № 31. P. 99-110.

4. Калашникова С. А. Организация процесса создания дистанционных курсов в высшем учебном заведении : Теория и практика дистанционного обучения : монография. Москва : МГУ, 2003. С. 112-115.

5. Кращенко Ю. П. Особливості організації системи студентського самоврядування. Витоки педагогічноі майстерності. 2009. Вип. 6. С. 255-262.

6. Lisova, S. V. The problem of ensuring the quality of higher education from the standpoint of a systematic approach. Professional pedagogical education: system research: monograph / ed. O. A. Dubaseniuk. Zhytomyr : ZhSU Publishing House. I. Franko, 2015. S. 160-172. 238 s.

7. Ріпко І. В. Особливості становлення лідерського потенціалу у студентів вищих навчальних закладів. Україна $i$ світ: гуманітарно-технічна еліта та сочіальний прогрес. 2010. № 2. С. 27-33. 


\section{REFERENCES}

1. Burns, J. M. Leadership. New York : Harper \& Row, 1978. 355 p.

2. Goleman, D. Working with emotional intelligence. Bantam, 1998. 147 p.

3. Bergiel, B. J., Bergiel, E. B., Balsmeier, P. W. (2008). Nature of virtual teams: a summary of their advantages and disadvantages. Management Research News. 2008. № 3 1. P. 99-110.

4. Kalashnikova, S. A. Organizatsiya protsessa sozdaniya distantsionnykh kursov v vysshem uchebnom zavedenii [Organization of the process of creating distance courses in a higher educational institution] Teoriya i praktika distantsionnogo obucheniya: [monogr.] Moscow : MGU, 2003. pp. 112-115 [in Russian].

5. Krashchenko, Yu. P. Osoblivostí organízatsîi sistemi students'kogo samovryaduvannya [Features of the organization of the student system self-government] Origins of pedagogical skill: collection. Science. wash. Vytoky pedagogíchnoyi maysterností. 2009. Vyp. 6. P. 255-262 [in Ukrainian].

6. Lisova, S. V. Problema zabezpechennya yakosti vyshchoyi osvity z pozytsiy systemnoho pidkhodu. [The problem of ensuring the quality of higher education from the standpoint of a systematic approach.] Professional pedagogical education: system research: monograph / ed. O. A. Dubaseniuk. Zhytomyr: ZhSU Publishing House. I. Franko, 2015. Profesiyna pedahohichna osvita: systemni doslidzhennya: monohrafiya / za red. O. A. Dubasenyuk. Zhytomyr: Vyd-vo ZHDU im. I. Franka, 2015. P. 160-172. 238 p. [in Ukrainian].

7. Rípko Í. V. Osoblivostí stanovlennya líders'kogo potentsíalu u studentív vishchikh navchal'nikh zakladív [Features of the formation of leadership potential in students of higher educational institutions] Ukraïna i svit: gumanitarno-tekhnichna yelíta ta sotsial’niy progress Mízhnar. nauk.-teor. Konfencia. 2010. № 2. P. 27-33 [in Ukrainian]. 